IZA DP No. 5683

Europe Agreements and Trade Balance:

Evidence from Four New EU Members

Guglielmo Maria Caporale

Christophe Rault

Robert Sova

Anamaria Sova

April 2011 


\title{
Europe Agreements and Trade Balance: Evidence form Four New EU Members
}

\author{
Guglielmo Maria Caporale \\ Brunel University, CESifo and DIW Berlin \\ Christophe Rault \\ LEO (Laboratoire d'Economie d'Orléans), \\ CESifo and IZA \\ Robert Sova \\ Bucharest Academy of Economic Studies
}

\author{
Anamaria Sova \\ E.B.R.C. Bucharest
}

\section{Discussion Paper No. 5683 \\ April 2011}

\author{
IZA \\ P.O. Box 7240 \\ 53072 Bonn \\ Germany \\ Phone: +49-228-3894-0 \\ Fax: +49-228-3894-180 \\ E-mail: iza@iza.org
}

\begin{abstract}
Any opinions expressed here are those of the author(s) and not those of IZA. Research published in this series may include views on policy, but the institute itself takes no institutional policy positions.

The Institute for the Study of Labor (IZA) in Bonn is a local and virtual international research center and a place of communication between science, politics and business. IZA is an independent nonprofit organization supported by Deutsche Post Foundation. The center is associated with the University of Bonn and offers a stimulating research environment through its international network, workshops and conferences, data service, project support, research visits and doctoral program. IZA engages in (i) original and internationally competitive research in all fields of labor economics, (ii) development of policy concepts, and (iii) dissemination of research results and concepts to the interested public.
\end{abstract}

IZA Discussion Papers often represent preliminary work and are circulated to encourage discussion. Citation of such a paper should account for its provisional character. A revised version may be available directly from the author. 
IZA Discussion Paper No. 5683

April 2011

\section{ABSTRACT}

\section{Europe Agreements and Trade Balance: Evidence form Four New EU Members*}

This paper analyses the trade balance effects of Europe agreements (EA) between the EU15 and four new EU members from Central and Eastern Europe (CEEC-4) using both static and dynamic panel data approaches. Specifically, the system Generalized Method of Moments (GMM, Blundell and Bond, 1998) and recently developed econometric methods such as the Correlated Common Estimation Pooled - Hausman-Taylor (CCEPHT, Serlenga and Shin, 2007) are applied to analyse the effects of the agreement variable. Our estimation results indicate a positive and significant impact of EA on trade flows. However, there is an asymmetric impact of the agreement variable on the trade balance, exports and imports being affected in different ways, which results in a trade balance deficit in the CEEC-4.

JEL Classification: E61, F13, F15, C25

Keywords: regionalisation, trade flows, trade balance, panel data methods

Corresponding author:

Christophe Rault

CNRS UMR 6221

University of Orleans

Rue de Blois-B.P.6739

45067 Orléans Cedex 2

France

E-mail: christophe.rault@univ-orleans.fr

\footnotetext{
* We are very grateful to two anonymous referees for helpful comments and suggestions on an earlier draft of this paper. The usual disclaimer applies.
} 


\section{Introduction}

Trade liberalisation represents one of the most important developments in the world economy in the last three decades. Many countries have liberalised their trade regime over that period of time, either unilaterally or as part of multilateral initiatives, in the pursuit of economic growth, a more efficient allocation of resources, greater competition, an increase in capital accumulation and technical progress. The implications of trade liberalisation for the trade balance are uncertain because they depend on its relative impact on export and import growth. The existing empirical literature generally finds a positive impact on both imports and exports (Thomas et al., 1991; Soloaga and Winters, 1999; Santos-Paulino, 2002; Carrère, 2006; Rault et al., 2008; Caporale et al., 2009); only a few studies do not (see, e.g., Greenaway and Sapsford, 1994; Jenkins, 1996). Jenkins (1996) analyses the impact of trade liberalization on Bolivian manufactured exports and finds that the improved export performance is largely the result of a more realistic and more stable real exchange rate after 1985, while trade policy reforms had little impact. Greenaway and Sapsford (1994) also find limited support for a positive impact of trade liberalisation on exports, some possible explanations being the diversity of trade policy measures used in their analysis as well as the difficulties of dating the liberalisation episodes. Other contributions examine the effects of trade liberalisation on the trade balance as a whole (UNCTAD, 1999; Santos-Paulino and Thirlwall, 2004; Wu and Zeng, 2008; Caporale et al., 2008), and find that liberalisation worsens it by stimulating imports more than exports.

In our paper we focus only on the specific case of association agreements between the CEEC-4 (i.e. Hungary, Poland, Bulgaria and Romania) and the EU-15 (i.e. Austria, Belgium-Luxemburg, Denmark, England, Finland, France, Germany, Greece, Holland, Ireland, Italy, Portugal, Spain, Sweden) instead of analysing the impact of all free trade agreements on the CEEC-4 trade balance. One of the reasons is that our analysis concerns the impact of trade liberalisation in the context of the trade and economic integration of these countries into the European Union. These agreements provided the legal framework for trade relationships between the candidate countries and the EU-15 and played a key 
role for the integration process of the CEEC-4 countries. They involved much more than the typical regional trade agreements, namely not only the elimination of trade barriers among members, but also their harmonisation vis-à-vis third countries and, more importantly, the harmonisation of domestic sectoral policies, the eventual aim being economic integration into the EU. In fact, after the signature of the FTAs the EU-15 have rapidly become the main partner of the CEEC-4 countries, approximately $60 \%$ of their trade being with their EU partners. Therefore, trade flows between the CEEC-4 and the EU-15 account to a large extent for trade balance adjustments in these countries.

Our econometric analysis tries to determine the effects of association agreements on trade flows and on the trade balance. We are particularly interested in the symmetric or asymmetric nature of their effects on the two components of trade (exports and imports) and their implications for the trade balance. Specifically, we analyse the impact of association agreements in two different and complementary ways, namely by estimating first the effects on imports and exports separately in order to compare their elasticities and to see whether trade liberalisation has affected import or export growth more, and then the effects on the trade balance as a whole. For this purpose, we select two CEEC countries which belong to the first accession wave (Hungary and Poland) and two belonging to the second one (Bulgaria and Romania). Each of these two groups of countries has similar macroeconomic indicators and political structure. ${ }^{5}$ The countries belonging to the first wave signed the association agreements with the EU in 1991 and have since become important trade partners of the EU-15 in terms of trade volume.

In our analysis we use the Generalized Method of Moments (GMM, Blundell and Bond, 1998) and recently developed econometric methods such as the Correlated Common Estimation Pooled - Hausman-Taylor (CCEP-HT, Serlenga and Shin, 2007). The former, provides solutions to the problems of simultaneity bias, reverse causality and omitted variables. Besides, it allows the researcher to control for individual specific effects and time effects, as well as to overcome the endogeneity bias. The CCEP-HT method

\footnotetext{
5 A larger sample including all countries from Central and Eastern Europe will be analysed in future research.
} 
combines the Correlated Common Effects Pooled (CCEP) estimator proposed by Pesaran (2006) with the Hausman-Taylor (HT) instrument variable approach and is suitable to estimate consistently a gravity model in heterogeneous panels with common time-specific factors. In more detail, it allows for unobserved common time-specific factors with heterogeneous responses across the cross-section units. Serlenga and Shin (2007) performed a Monte Carlo study and found that the small sample performance of the CCEP-HT estimator is far superior to that of the conventional approach using fixed time dummies in the presence of unobserved heterogeneous common factor in panels. Using these approaches we provide some new and reliable empirical evidence on the effects of free trade agreements in Bulgaria, Hungary, Poland and Romania, countries for which

these issues have rarely been investigated despite their importance (Caporale et al., 2008), especially in view of the sizable trade deficit they experienced during the period 1987-2007. The model includes a dummy variable which represents the association agreement to estimate its impact on exports and imports respectively and the consequences for the trade balance.

The structure of this paper is as follows. Section 2 contains some background information on trade liberalisation and association agreements. Section 3 provides the theoretical framework for our analysis. Section 4 outlines the econometric methodology. Sections 5 and 6 provide details of the estimated model and the empirical results. Section 7 offers some concluding remarks.

\section{Trade liberalisation and association agreements}

Regional trade liberalisation has been particularly successful in Western Europe since the 1960s. In the 1990s deeper economic integration was sought with a view to a future monetary union. The Common Market was achieved in 1993 by eliminating trade, administrative and technical barriers and hence transaction costs. In January 1999, with the introduction of the euro, it was expected that currency conversion costs and exchange rate volatility would also be reduced. 
Externally, the EU was faced with the economic and political challenge represented by the Eastern European countries, and aimed to provide a framework to facilitate their gradual economic and political integration. After 1990, the European Council had discussed the possibility of EU enlargement to include new member countries from Central and Eastern Europe. All these countries signed association agreements with the EU, which created a free trade area (see Table 1).

\section{Table 1: Signature and entry into force of Association Agreements}

\begin{tabular}{|c|c|c|}
\hline CEEC & Signature & Entry into force \\
\hline Hungary & 16 December 1991 & 1 February 1994 \\
\hline Poland & 16 December 1991 & 1 February 1994 \\
\hline Romania & 1 February 1993 & 1 February 1995 \\
\hline Czech Republic & 4 October 1993 & 1 February 1995 \\
\hline Slovakia & 4 October1993 & 1 February 1995 \\
\hline Bulgaria & 8 March 1993 & 1 February 1995 \\
\hline Latvia & 12 June 1995 & 1 February 1996 \\
\hline Estonia & 12 June 1995 & 1 February 1996 \\
\hline Lithuania & 12 June 1995 & 1 February 1996 \\
\hline Slovenia & end of 1995 & 1 June 1996 \\
\hline
\end{tabular}

Source: European Commission report, 2000.

In 1993, the European Council meeting in Copenhagen gave the CEECs the option of joining the EU once they had fulfilled a series of economic and political conditions, i.e. the accession criteria. In 1995, the Commission specified the required steps for entry into the single market. In July 1997, at a meeting of the European Council in Luxemburg accession negotiations were started with six candidates for the first wave of enlargement (Cyprus, Hungary, Poland, Czech Republic, Slovenia, and Estonia), known as "Luxemburg Group". In 1999, at a further meeting in Helsinki the European Council decided to enter into membership negotiations with the "second wave", also called the "Helsinki Group", (Bulgaria, Latvia, Lithuania, Malta, Romania and Slovakia). Finally, 
in 2004, ten candidate nations became official members of the EU, which from 2007 has comprised 27 members.

The association agreements (later completed by a series of protocols) provided the legal framework for trade relationships between the candidate countries and the EU. A time schedule was specified for trade liberalisation between the signatories, the EU committing itself to a faster reduction of trade barriers than the Central and Eastern European countries.

International trade theory suggests that the benefits for developing countries from trade liberalisation with industrialised countries are access to a much greater variety of productive inputs and consumer goods, and technical advances incorporated in imports of capital or intermediate and consumption goods. In particular, the impact of the association agreements on trade flows (exports and imports) is usually analysed using a gravity model as the theoretical framework (as in the present study). This class of models was inspired by Newton's gravity law. Following the early contributions of Tinbergen (1962) and Pöyhönen (1963), "New trade theory" provided theoretical justifications in terms of imperfect competition, increasing returns of scale, and transport costs. Linnemann (1966) proposed a gravity model derived from a general equilibrium model explaining exports of country $i$ to country $j$ in terms of the interaction of three factors: potential supply of exports of country $i$, potential demand of imports from country $j$ and a factor representing trade barriers. The model was extended by Anderson (1979), Bergstrand (1985), Helpman and Krugman (1985). Bergstrand (1989) and Anderson and van Wincoop (2003) provide further theoretical underpinnings for the gravity model.

In order to analyse the impact of trade liberalization on trade balance as a whole we use a balance of payments framework. There are three main theoretical approaches to balance of payments adjustments, known as elasticities, absorption and monetary approaches. We briefly review them in the next section. 


\section{Theoretical framework}

The elasticities approach emphasises the role of relative prices (domestic versus foreign) in balance of payments adjustments and focuses on the effects of changes in exchange rates. The essence of this approach is that, in partial equilibrium, a currency devaluation can improve the trade balance (Bickerdike, 1920; Robinson, 1947; Metzler, 1948). A sufficient condition for a successful devaluation is the Marshall -Lerner condition which is derived in a two-country-two-commodity model on the assumption that underemployment exists in each country. This condition implies that a real depreciation improves the trade balance, starting from a situation of balanced-trade, only if the sum of the absolute value of the demand elasticities for exports and imports exceeds unity. The trade balance in foreign currency terms can be defined as:

$$
T B=V_{f x}-V_{f m}
$$

where: $\mathrm{V}_{\mathrm{f}} \mathrm{X}$ represents the foreign value of exports; $\mathrm{V}_{\mathrm{fm}}$ stands for the foreign value of imports;

$$
\begin{aligned}
& V_{f x}=p_{f x} X \\
& V_{f m}=p_{f m} M
\end{aligned}
$$

$\mathrm{X}, \mathrm{M}$ are the quantities of exports and imports; $\mathrm{p}_{\mathrm{x}}, \mathrm{p}_{\mathrm{m}}$ are foreign export price and foreign import price

The effect of the change in the exchange rate (devaluation) on the trade balance is given by:

$$
\Delta T B=V_{f x}\left(\frac{\Delta X}{X}+\frac{\Delta p_{f x}}{p_{f x}}\right)+V_{f m}\left(-\frac{\Delta M}{M}-\frac{\Delta p_{f m}}{p_{f m}}\right)
$$

Note that :

$$
\begin{array}{ll}
e_{x}=\frac{\Delta X}{X} / \frac{\Delta p_{d x}}{p_{d x}}, \quad e_{m}=\frac{\Delta M}{M} / \frac{\Delta p_{f m}}{p_{f m}} & \text { home export supply elasticity; } \\
\text { foreign import supply elasticity } \\
\eta_{x}=-\frac{\Delta X}{X} / \frac{\Delta p_{f x}}{p_{f x}}, \quad \eta_{m}=-\frac{\Delta M}{M} / \frac{\Delta p_{d m}}{p_{d m}} & \text { foreign export demand elasticity; } \\
\text { home import demand elasticity }
\end{array}
$$

Thus, the equation becomes: 


$$
\Delta T B=V_{f x} \frac{e_{x}\left(\eta_{x}-1\right)}{e_{x}+\eta_{x}}+V_{f m} \frac{\eta_{m}\left(e_{m}+1\right)}{\eta_{m}+e_{m}}
$$

As mentioned above, the condition for a devaluation to improve the trade balance is:

$$
\frac{V_{f m}}{V_{f x}}\left|\eta_{m}\right|+\left|\eta_{x}\right|>1
$$

The elasticities approach was criticised for not taking into consideration the various multiplier effects and because it is a partial equilibrium analysis.

The absorption approach states that any improvement in the balance of payments requires an increase in income over total domestic expenditure (Meade, 1951; Alexander, 1959). Thus, if the devaluation leads to a smaller increase in expenditure (absorption) than in income, the trade balance will be improved. A deficit implies that people spend more than their income. The trade balance is defined as:

$$
\mathrm{TB}=\mathrm{Y}-\mathrm{E}
$$

where $\mathrm{Y}$ stands for domestic income and $\mathrm{E}$ represents total domestic expenditure (absorption). In contrast to the elasticities approach, the absorption approach is a general equilibrium analysis which takes a more macroeconomic view of the balance of payment. Nevertheless, it has been criticised for ignoring the inflationary effects of a devaluation and capital movements, as well as for being inappropriate for the full employment case.

The monetary approach analyses the balance of payments from the point of view of the supply and demand of money in order to determine the overall balance of payments position of the economy (Prais, 1961; Johnson, 1977; Mundell, 1971). This approach is based on the deficit or excess demand for goods and securities that can lead to the accumulation of money. When there is excess demand for money which is satisfied with money from abroad, the trade balance improves. In the case of excess supply of money satisfied by the Central Bank, the trade balance worsens. A reduction in the money supply may produce deflation. 
In what follows we use a trade balance equation which incorporates both the elasticity and absorption approaches of the balance of payments. Thus, the trade balance model becomes:

$$
t b=\gamma_{0}+\gamma_{1} z+\gamma_{2} y+\gamma_{3} p+\eta
$$

where: $\mathrm{p}$ represents the real exchange rate; $\mathrm{z}, \mathrm{y}$ are the foreign and domestic income rate. In the existing literature, the trade balance is usually modelled as a function of domestic income, foreign income, trade liberalisation, the exchange rate, the money supply, the fiscal deficit/surplus as a percentage of GDP, productivity, and Foreign Direct Investment (see Duasa, 2007, Gagnon, 2007, Tang 2008, Gil-Alana et al., 2008). In the present case, as we focus on the impact of the association agreements on CEEC imports and exports and their trade balance as a whole, the main explanatory variables of the model are income of partner countries, transport costs, real exchange rate and the signing of a Europe agreement.

\section{The Econometric Methodology}

In our analysis we use the CCEP-HT method for the static analysis and the GMM one ${ }^{6}$ for the dynamic analysis in order to highlight the impact of the Europe Agreements (EA) on the trade flows and trade balance between the CEEC-4 and the EU-15. The CCEP-HT is an econometric procedure that yields consistent estimates of the coefficients of models such as the gravity model in a panel data context with time-varying and time-invariant effects. Empirical studies have highlighted the importance of taking into account the presence of time specific effects in order to capture business cycle effects as well as other common macroeconomic shocks by introducing fixed time dummies in the panel regression (Matyas, 1997; Egger, 2002). These studies used panel data approaches based on homogeneous fixed time dummies. However, the homogeneity assumption is too

\footnotetext{
6 There are two types of GMM estimators for dynamic panels: (i) The first-differenced GMM estimator (Arellano and Bond, 1991); (ii) The system GMM estimator (Blundell and Bond, 1998). The former eliminates specific individual effects through first-differencing of a single equation, and then instruments the explanatory variables using their lagged values in levels. The latter involves the estimation of a system containing both first-differenced and levels equations, where the variables are instrumented by their first differences.
} 
restrictive. Thus, some recent papers emphasise the importance of heterogeneous unobserved common time effects in order to obtain unbiased results (Phillips and Sul, 2003; Pesaran, 2006). The CCEP-HT estimator combines the CCEP estimator (Pesaran, 2006) ${ }^{7}$ and the Hausman-Taylor instrumental variable estimation technique and allows for both observed and unobserved common factors with heterogeneous individual responses.

For our dynamic analysis we use the system GMM (SYS-GMM) method for dynamic panels that involves the estimation of a system containing both first-differenced and levels equations, where the variables are instrumented by their first differences. To test the validity of the lagged variables as instruments, we use the Sargan test of overidentification. By construction the error term in first differences is autocorrelated of order one, but it should not be autocorrelated of order two. To test this hypothesis, Arellano and Bond (1991) recommend using an (AR2) autocorrelation test, where the null hypothesis is the absence of second-order autocorrelation in the residuals of the equation in differences. A problem that often arises in the application of the difference and system GMM is instrument proliferation. Roodman (2009b) reviews its risks and describes the techniques for limiting them, suggesting that the instruments be collapsed, as we do. For more details on the GMM methods see Roodman (2009a, 2009b) and for CCEP-HT one the Appendix.

\section{Econometric analysis}

We proceed in two stages. First, we estimate the impact of Europe agreements on the two components of trade (exports and imports) using the gravity estimation, which gives a first indication of the overall effects on the trade balance. Second, we estimate directly the impact on the trade balance. For this purpose, we use as dependent variable the ratio of a country's exports to imports and also the ratio of the trade balance to GDP in order to take into account size differences between countries. The empirical model for the trade

\footnotetext{
${ }^{7}$ The CCEP estimator is obtained as the generalized within estimator applied to the panel data regression augmented with cross-sectional averages of $y_{i t}$ and $\mathbf{x}_{\text {it }}$ that consistently replace unobserved common timespecific effects (Serlenga and Shin, 2007).
} 
balance model is based on equation (10) but also includes additional variables. The estimated gravity equation and trade balance model are the following:

$$
\begin{gathered}
\text { In a static framework: } \\
\log \left(X_{i j t}\right)=a_{0}+a_{1} \log \left(G D P_{i t}\right)+a_{2} \log \left(G D P_{j t}\right)+a_{3} \log \left(D G D P T_{i j t}\right)+ \\
a_{4} \log \left(D i s t_{i j}\right)+a_{5} \log \left(R E R_{i j t}\right)+a_{6} E A_{i j t}+a_{7} P S_{i t}+a_{8} C B_{i j}+a_{9} L l k_{i j}+\varepsilon_{i j t}
\end{gathered}
$$

and

$$
\begin{aligned}
& \log \left(M_{i j t}\right)=\beta_{0}+\beta_{1} \log \left(G D P_{i t}\right)+\beta_{2} \log \left(G D P_{j t}\right)+\beta_{3} \log \left(D G D P T_{i j t}\right)+ \\
& +\beta_{4} \log \left(D i s t_{i j}\right)+\beta_{5} \log \left(R E R_{i j t}\right)+\beta_{6} E A_{i j t}+\beta_{7} P S_{i t}+\beta_{8} C B_{i j}+\beta_{9} L l k_{i j}+\delta_{i j t}
\end{aligned}
$$

* In a dynamic framework:

$\log \left(X_{i j t}\right)=a_{0}+a_{1} \log \left(X_{i j t-1}\right)+a_{2} \log \left(G D P_{i t}\right)+a_{3} \log \left(G D P_{j t}\right)+a_{4} \log \left(D G D P T_{i j t}\right)+$ $a_{5} \log \left(D_{i s t_{i j}}\right)+a_{6} \log \left(R E R_{i j t}\right)+a_{7} E A_{i j t}+a_{8} P S_{i t}+a_{9} C B_{i j}+a_{10} L l k_{i j}+\varepsilon_{i j t}$

and

$$
\begin{aligned}
& \log \left(M_{i j t}\right)=\beta_{0}+\beta_{1} \log \left(M_{i j t-1}\right)+\beta_{2} \log \left(G D P_{i t}\right)+\beta_{3} \log \left(G D P_{j t}\right)+\beta_{4} \log \left(D G D P T_{i j t}\right)+ \\
& +\beta_{5} \log \left(D i s t_{i j}\right)+\beta_{6} \log \left(R E R_{i j t}\right)+\beta_{7} E A_{i j t}+\beta_{8} P S_{i t}+\beta_{9} C B_{i j}+\beta_{10} L l k_{i j}+\delta_{i j t}
\end{aligned}
$$

and

$$
\begin{aligned}
& \log \left(T B_{i j t}\right)=\gamma_{0}+\gamma_{1} \log \left(T B_{i j t-1}\right)+\gamma_{2} \log \left(G D P R_{i t}\right)+\gamma_{3} \log \left(G D P R_{j t}\right)+ \\
& +\gamma_{4} \log \left(D G D P T R_{i j t}\right)+\gamma_{5} \log \left(R E R_{i j t}\right)+\gamma_{6} E A_{i j t}+\gamma_{7} P S_{i t}+\gamma_{8} C B_{i j}+ \\
& +\gamma_{9} L l k_{i j}+\eta_{i j t} \\
& \log \left(T B_{i j t} / G D P_{i t}\right)=\gamma_{0}+\gamma_{1} \log \left(T B_{i j t-1}\right)+\gamma_{2} \log \left(G D P R_{i t}\right)+\gamma_{3} \log \left(G D P R_{j t}\right)+ \\
& +\gamma_{4} \log \left(D G D P T R_{i j t}\right)+\gamma_{5} \log \left(R E R_{i j t}\right)+\gamma_{6} E A_{i j t}+\gamma_{7} P S_{i t}+\gamma_{8} C B_{i j}+ \\
& +\gamma_{9} L l k_{i j}+\eta_{i j t}
\end{aligned}
$$

where:

$\mathrm{X}_{\mathrm{ijt}}$ and $\mathrm{M}_{\mathrm{ijt}}$ denote exports and imports respectively between countries $\boldsymbol{i}$ and $\boldsymbol{j}$ at time $\boldsymbol{t}$ with $\mathrm{i} \neq \mathrm{j}$ (millions of dollars); $\mathrm{TB}_{\mathrm{ijt}}$ stands for the trade balance defined as the ratio of a country's exports to imports; $\mathrm{TB}_{\mathrm{ijt}} / \mathrm{GDP}$ represents the ratio of trade balance to GDP; the other variables are defined in Table 2. 
Table 2: Variable definitions and their expected signs

\begin{tabular}{|c|c|c|}
\hline Variables & Explanation of variables & $\begin{array}{l}\text { Expected } \\
\text { signs }\end{array}$ \\
\hline$\alpha_{0} / \beta_{0} / \gamma_{0}$ & intercept & \\
\hline $\mathrm{GDP}_{\mathrm{it}}, \mathrm{GDP}_{\mathrm{jt}}$ & $\begin{array}{l}\text { Gross Domestic Product of country } i \text { and country } j \text { in } \\
\text { Parity Power Purchasing (PPP) (constant } 1995 \text { US\$) }\end{array}$ & + \\
\hline DGDPT $_{i j t}$ & $\begin{array}{l}\text { difference in GDP per capita in PPP between partners } \\
\text { - a proxy for economic differences and comparative } \\
\text { advantage intensity }\end{array}$ & $+/-$ \\
\hline $\mathrm{GDPR}_{\mathrm{it},}, \mathrm{GDPR}_{\mathrm{jt}}$ & $\begin{array}{l}\text { real GDP growth of country } i / \text { country } j \text { (constant } \\
1995 \text { US\$) }\end{array}$ & $+/-$ \\
\hline DGDPTR $_{\mathrm{ijt}}$ & difference in real GDP per capita between partners & $+/-$ \\
\hline Dist $_{i j}$ & distance between country $i$ and country $j$ (kilometers) & - \\
\hline $\mathrm{RER}_{\mathrm{ijt}}$ & real exchange rate (price competitiveness) & $+/-$ \\
\hline $\mathrm{EA}_{\mathrm{ijt}}$ & $\begin{array}{l}\text { dummy variable that is equal to } 1 \text { if country } i \text { and } \\
\text { country } j \text { have signed a regional agreement, and zero } \\
\text { otherwise }\end{array}$ & + \\
\hline $\mathrm{PS}_{\mathrm{it}}$ & $\begin{array}{l}\text { dummy variable that is equal to } 1 \text { if a country has } \\
\text { political stability, and zero otherwise }\end{array}$ & + \\
\hline $\mathrm{CB}_{\mathrm{ij}}$ & $\begin{array}{l}\text { dummy variable that is equal to } 1 \text { if country } i \text { and } \\
\text { country } j \text { have a common border, and zero otherwise }\end{array}$ & + \\
\hline $\mathrm{Llk}_{\mathrm{ij}}$ & $\begin{array}{l}\text { dummy variable that is equal to } 1 \text { if country } i \text { and } \\
\text { country } j \text { are land-locked, and zero otherwise }\end{array}$ & + \\
\hline$\varepsilon_{\mathrm{ijt}} / \delta_{\mathrm{ijt}} / \eta_{\mathrm{ijt}}$ & $\begin{array}{l}\text { the disturbance term, which is assumed to be } \\
\text { normally distributed with a zero mean and a constant }\end{array}$ & \\
\hline
\end{tabular}


\begin{tabular}{|l|l|l|}
\hline & variance for all observations and to be uncorrelated. & \\
\hline
\end{tabular}

On the basis of the well-known Keynesian foreign trade multiplier one would expect only imports to be a (positive) function of national income growth. Thus, higher domestic income should increase imports and affect negatively the trade balance, whereas an increase in partners' income should have a positive effect by stimulating the domestic country's exports.

The hypothesis that devaluation can improve the trade balance is rooted in the MarshallLerner condition (ML) (Marshall, 1923; Lerner, 1944), which states that the absolute values of the sum of import and export demand elasticities must exceed unity for a devaluation to have a positive effect on the trade balance. In this case, there might be a negative effect in the short run but there will be an improvement in the long run (this is the so-called "J-curve" effect) ${ }^{8}$. Here the real exchange rate $\mathrm{RER}_{\mathrm{ijt}}$ is defined as:

$$
R E R_{i j t}=N E R_{i j t} \times P_{i t} / P_{j t}
$$

where $\mathrm{NER}_{\mathrm{jt}}$ is the nominal exchange rate and $\mathrm{P}_{\mathrm{i}}(\mathrm{j})$ is the consumer price index. The validity of the ML condition is the underlying assumptions for those supporting devaluation as a means to improve the trade balance. A depreciation of the home currency (CEEC-4) relative to the foreign currency (EU-15) (i.e., a decline in RER) should lead to higher exports and lower imports for the home country and thus improve the trade balance, and consequently RER should have a negative coefficient in the trade balance equation. As for the impact of liberalisation on the trade balance, this is an empirical issue given the ambiguity of theory (Santos-Paulino and Thirlwall, 2004).

\footnotetext{
${ }^{8}$ As a devaluation of the exchange rate means a decrease (increase) in export (import) prices, export (import) demand will increase (decrease). The net effect on the trade balance will depend on price elasticities. If export (import) elasticity is high, export (import) demand will increase (decrease) proportionately more than the decrease (increase) in prices, and total export (import) revenue will increase (decrease). Empirically, it has been found that goods tend to be inelastic in the short run, as it takes time to change consumption patterns. Thus, the Marshall-Lerner condition is not met, and a devaluation is likely to worsen the trade balance initially. In the long run, consumption will adjust to the new prices, and the trade balance will improve. This is known as the J-curve effect.
} 
The data source is the Chelem data base for trade, GDP, GDP/capita, nominal exchange rate and population; the Cepii data base for geographic distance, contiguity and landlocked countries; the Freedom House for political stability and the World Bank World Tables for the consumer index price. The estimation period goes from 1987 to 2006, i.e. 20 years for a sample including the EU-15 and the CEEC-4.

\section{Estimation results}

This section summarises the results from the estimation of model using the static and dynamic analysis. To establish whether the effect on the trade flows is symmetric or asymmetric, we estimate separately the effects on exports (Table 3) and imports (Table 4). The association agreements appear to have had a positive impact on the two components of CEEC-4 trade with the EU-15, but the coefficients are higher for imports than for exports, indicating asymmetry and resulting in a trade deficit for the CEEC-4. This conclusion is supported by the results obtained with both estimation methods (CCEP-HT and GMM) even if the positive effect of the association agreement is found to be stronger in a static than dynamic framework. These findings are consistent with the theory of regional integration: trade agreements facilitate trade exchanges between partners.

Moreover, movements of the trade balance over time reveal that imports increase more quickly than exports (see Chart 1). Some potential explanations are the lack of product competitiveness in the European market, increasing vertical FDI, importing intermediate goods necessary for their production process and a greater preference of consumers for products from the EU.

Concerning the other variables, all the estimated coefficients are statistically significant and have the expected signs, which are consistent with the gravity model: we find a positive effect on trade flows of country size, economic distance, political stability, common border, and association agreements, and a negative impact of geographical distance. Political stability influences positively both exports and imports of these countries with their European partners and increases with the rule of law and democracy. 
A stable political environment is conducive to economic stability and encourages countries to trade. By contrast, political and economic instability generates lack of confidence about the business environment and reduces trade volumes. The political regime is also a non-economic determinant of trade flows.

Geographic distance has the negative expected sign and is an important determinant of trade flows between the CEEC-4 and the EU-15. This variable is a proxy for transport and transaction costs: the closer partner countries are, the higher their trade flows will be. A common border also has a positive influence on trade since neighbouring countries incur lower transport costs. As for the real exchange rate, a devaluation of the currency is found to improve the trade balance, implying that the Marshall-Lerner (ML) condition is satisfied. However, it might also cause inflationary spirals and domestic market distortions, reduce growth and have undesirable redistributive effects.

\section{INSERT TABLE 3 AND 4 ABOUT HERE}

Regarding the effects of the agreements on the trade balance as a whole, visual inspection would suggest that they lead to a trade deficit for the CEEC-4 with respect to the EU-15. Here we use only the GMM method. The reason is that trade imbalances and the corresponding capital flows need an explicit intertemporal macroeconomic framework for analysing them. Lags are included in the equation to capture the dynamic adjustment. The GMM estimates indicate a negative impact (see Table 5). One of the reasons is that the economic and technological caching-up process vis-à-vis the EU-15 has also meant higher imports of new equipment for modernising the CEEC industries. Besides, the development of the financial system in these countries had led to a rapid growth of consumer credit (European banks being the main source of credit - see Caporale et al., 2009), which has contributed to widening current account deficits through increased demand for imported consumer goods and currency appreciation. Overall, trade liberalisation has resulted in an increase in the demand for foreign goods, these countries experiencing inflows of both consumer goods and intermediate/capital goods. 


\section{INSERT TABLE 5}

As for the others variables, domestic income growth (CEEC-4) has a significant negative effect (as expected) and income growth in the partner countries (EU-15) has a significant positive effect (as expected). Finally, less economic distance between trading partners is associated with an improvement in the trade balance reflecting the development of intraindustry trade, which involves simultaneous export and import flows of comparable size within the same industry. Political stability, contiguity and landlocked are positive but their influence is relatively low.

Concerning the results for trade balance as proportion of GDP using the GMM method (see Table 5), it can be seen that trade liberalisation has worsened the trade balance by over $0.12 \%$ of GDP. The evolution over time of the trade balance to GDP ratio for the CEEC-4 vis-à-vis the EU-15 is consistent with the econometric results and shows its negative contribution to GDP (see Chart 1b). The other coefficients have the expected signs. Higher domestic GDP growth leads to a deterioration of the trade balance, while higher foreign GDP growth improves a country's trade balance. Specifically, a $1 \%$ growth in domestic income worsens the trade balance by $0.02 \%$ of GDP while a $1 \%$ growth in partners' income improves it by $0.05 \%$. A real exchange rate depreciation also tends to lead to an improvement of the trade balance.

The chosen GMM model specification passes all the standard diagnostic tests, in particular there is no evidence of residual autocorrelation, and the validity of the instruments is confirmed by Sargan's test. The GMM results are better when the instruments are collapsed and fewer of them are used. In the case of the CCEP-HT approach, which provides more accurate predictions than the conventional one using fixed time dummies, all coefficients are statistically significant and with the expected signs. Overall, the coefficient of the agreement variable indicates a positive and significant impact on trade flows but an asymmetric effect on exports and imports 
Reassuringly, both methods lead to the same conclusions. As for the impact on the trade balance as a whole, this is found to be negative.

\section{Conclusions and policy implications}

This paper has analysed the impact of the association agreements on exports and imports and the trade balance of the CEEC-4 using a static and a dynamic panel data approach. These agreements represented the first step of the economic integration of Central and Eastern European countries into the EU. Consistently with theory, association agreements were found to have a positive and significant impact on exports and imports of the CEEC-4 to/from the EU-15. However, the estimated coefficients are higher for imports than for exports, which suggest trade asymmetry. This conclusion is supported by two methods used in our econometric analysis. In particular, for our sample of data, the agreements resulted in increasing trade deficits for the CEEC-4 countries, which is not desirable for economies still trying to catch up with the other EU members. Convergent or divergent dynamics of imports and exports are the driving force of trade balance changes. The evolution of exports, imports as well as of the trade balance over the estimation period for all CEEC-4 highlights the persistence and the deepening of the trade deficit (see Chart 2).

The lower impact of the agreement on CEEC-4 exports than imports can be interpreted in terms of low EU demand for CEEC-4 products reflecting their lack of attractiveness for European consumers, despite their price competitiveness based on comparative advantages due to lower labour costs. The centralised planning that characterised these countries until 1990 was not based on competitive trade and this why after the signature of the association agreement these countries found it difficult to compete in the EU market. Economic and technological gaps between the two groups of countries are still present: trade liberalisation did not lead to a restructuring of exports and to a development of the most innovative sectors of the economy. Instead, CEEC-4 exports are still represented mainly by labour-intensive products with lower added value. (see Rault et al., 2008) 
Others potential explanations for the trade deficit could be the increase of vertical FDI, the CEEC-4 importing intermediate goods necessary for their production process (see Caporale et al., 2008). Higher trade openness and the progressive liberalisation of capital flows resulting from the trade agreements have strongly influenced the behaviour of multinationals firms (Albu et al., 2009). Vertical FDI dominates in the CEEC countries (see Kaitila and Widgren, 1999). This type of investment is based on fragmentation of the production process to take advantage of lower costs in countries such as the CEEC-4. This inevitably entails a rise of intermediate and equipment good imports of these countries from the investors' countries - they now represent more than half of the CEEC4 total imports from the EU (see Chart 3).

Thus, trade liberalisation between the CEEC-4 and the EU-15 led to a deterioration of the trade balance for the former. This is not surprising, given the economic difficulties, reforms and restructuring associated with the transition process. Although a trade deficit reduces GDP, its overall effect should be assessed in each individual case. It is generally thought that trade liberalisation might increase welfare even if it produces a trade deficit. A controlled short-term trade deficit is manageable and sometimes may be necessary for development. The possible welfare gains are from trade creation: trade-creating FTAs should increase the welfare of the importing country, while trade-diverting FTAs should reduce it. A trade deficit can also have beneficial effects if it reflects productive investment, and if it increases consumers' spending power (through lower goods price) and competitiveness (through imported capital and equipment necessary for industrial restructuring that can improve productivity). In the case of CEEC-4, the rapid growth of consumer credit due to the development of the financial system and the rapid growth in imports of new equipments necessary for modernising the CEEC-4 industries increased total imports and thus contributed to the deficit. However, overall trade liberalisation may indeed enhance economic welfare by increasing product variety and through imports of intermediate goods incorporating more advanced technologies leading to better quality of products and competitiveness in the long run. 
The trade balance can be used as an indicator of competitiveness. The CEEC-4, in the process of catching-up with the others members of the EU, have registered a permanent deficit with the latter, which might raise some concerns, since a long-term trade deficit can trigger job losses, increase foreign debt and lead to currency crises. Obviously, it might be financed by international borrowing or by selling assets to foreign direct investment, but there are intergenerational effects implying that several generations will pay interests.

In order to reduce their trade deficit and to have a sustainable trade balance, the CEEC-4 countries would need instead more intra-industry trade with high added-value products so as to increase their export competitiveness towards the EU and to attract horizontal FDI, thereby achieving real convergence in terms of real $\mathrm{GDP}^{9}$. The poor performance of a specific industry may be improved by the implementation of reforms to boost production, by entrepreneurship, technological change, investment in physical and human capital and importing modern technology. A target-oriented industrial policy can also improve the trade balance through its effects on competitiveness, thereby increasing economic welfare.

Despite economic growth of these countries during the last decade, the CEEC-4 still has an important gap vis-à-vis the EU-15. Countries belonging to the first wave (Hungary and Poland) have achieved faster real convergence towards the EU in terms of GDP per capita, while those in the second wave (Bulgaria and Romania) have more catching-up to do: GDP per capita relative to the EU-25 average is still only $63 \%$ and $51 \%$ in the case of Hungary and Poland respectively, and 36\% and 35\% for Romania and Bulgaria respectively (source: IMF). 


\section{References}

[1] Albu L., Stancu I., Sova R., Sova A. (2009), "Patterns of Foreign Direct Investment in the new EU Countries", Romanian Journal of Economic Forecasting,2, 42-51.

[2] Alexander, S. S. (1959), "Effects of a devaluation: a simplified synthesis of elasticities and absorption approaches", American Economic Review, 49, 21-42.

[3] Anderson E. J. (1979), "A Theoretical Foundation for the Gravity Equation", American Economic Review, 69,106-116

[4] Anderson E. J., van Wincoop E. (2003),"Gravity with gravitas: a solution to the border effect puzzle “, American Economic Review, 93(1), 170-192

[5] Arellano M, Bond S. (1991), "Some Tests of Specification for Panel Data: Monte Carlo Evidence and an Application to Employment Equation", Review of Economic Studies, 58,277-297

[6] Bergstrand J.H. (1985), "The Gravity Equation in International Trade: some Microeconomic Foundations and Empirical Evidence", The Review of Economics and Statistics, 67(3), 474-481.

[7] Bergstrand J.H. (1989), "The Generalized Gravity Equation, Monopolistic Competition, and the Factor-Proportions Theory in International Trade", Review of Economics and Statistics, 71(1), 143-153.

[8] Bickerdike, C. F. (1920) "The instability of foreign exchange", The Economic Journal, 30(117), 118-122.

[9] Blundell R., Bond S. (1998), "Initial Conditions and Moment Restrictions in Dynamic Panel Data Models", Journal of Econometrics, 87(1), 115-143.

[10] Caporale G.M., Rault C., Sova R., Sova A. (2009), "On the bilateral trade effects of free trade agreements between the UE-15 and the CEEC-4 countries", Review of World Economics, 145(2),189-206.

[11] Caporale G.M., Rault C., Sova R., Sova A. (2008 ), "On the trade balance effects of free trade agreements between the UE-15 and the CEEC-4 countries", WP no. 08-10, Department of Economics and Finance, Brunel University, London.

[12] Caporale G.M., Rault C., Sova R., Sova A. (2009),"Financial Development and Economic Growth: Evidence from Ten New EU Members", DIW working paper no.940. 
[13] Carrère C. (2006), "Revisiting the Effects of Regional Trading Agreements on Trade Flows with Proper Specification of the Gravity Model”, European Economic Review, 50 (2), 223-247.

[14] Duasa J. (2007), "Determinants of Malaysia trade balance: An ARDL bound testing approach”, Global Economic Review, 36(1), 89-102

[15] Egger P. (2002), "A note on the proper econometric specification of the gravity equation", Economics Letters, 66, 25-31

[16] Gagnon J. (2007),"Productive Capacity, Product Varieties, and the Elasticities Approach to the Trade Balance", Review of International Economics, 15(4),639-659

[17] Gil-Alana A.L, Luqui N., Cunado J. (2008), "Trade Balance and Exchange Rate:Unit Roots, Co-integration and Long Memory in the US and the UK", Economic Notes by Banca Monte dei Paschi di Siena SpA, 37(1),59-74

[18] Greenaway D., Sapsford D. (1994), "What does liberalisation do for exports and growth", Review of World Economics (Weltwirtschaftliches Archiv), 30,157-74.

[19] Helpman E., Krugman P.R. (1985), "Market Structure and Foreign Trade: Increasing Returns, Imperfect Competition, and the International Economy", Cambridge/Mass.: MIT Press

[20] Jenkins R. (1996),'Trade performance and export performance in Bolivia", Development and Change, 27,693-716

[21] Johnson, H.G (1977), “The Monetary Approach to Balance of Payments Theory and Policy: Explanation and Policy Implications", Economica 44 (175), 217-229.

[22] Kaitila V., Widgren M.T. (1999), "Revealed Comparative Advantage in Trade between the European Union and the Baltic Countries", The Research Institute of the Finnish Economy, Discussion Papers 697

[23] Lerner A.P. (1944), "The Economics of Control: Principles of Welfare Economics", New York : McMillan

[24] Linnemann H. (1966), “An Econometric Study of International Trade Flows", North Holland Publishing Company, Amsterdam

[25] Marshall A. (1923), "Money, Credit and Commerce", London, Macmillan.

[26] Matyas L. (1997), "Proper econometric specification of the gravity model", World Economy, 20, 363-368. 
[27] Meade, J. E. (1951), “The Theory of International Economic Policy”, The Balance of Payments", Oxford University Press, London.

[28] Metzler, L. A. (1948), "The Theory of International Trade” in Howard S. Ellis, A Survey of Contemporary Economics, vol. I (Homewood, IL).

[29] Mundell, R. A. (1971), “The International Distribution of Money in a Growing World Economy", in Bhagwati et al., editors, Trade, Balance of Payments and Growth.

[30] Pesaran M.H. (2006), "Estimation and inference in large heterogenous panels with a multifactor error structure", Econometrica,74,967-1012

[31] Phillips P.C.B, Sul D. (2003), "Dynamic panel estimation and homogeneity testing under cross section dependence", Econometrics Journal, 6, 217-259.

[32] Pöyhönen P. (1963) “A tentative model for the flows of trade between countries", Welwirtschftliches Archiv, 90, 93-100

[33] Prais, S. J. (1961) Some Mathematical Notes on the Quantity Theory of Money in an Open Economy, International Monetary Fund Staff Papers, 8 (2), 212-226.

[34] Rault C., Sova R., Sova A (2008), “The Role of Association Agreements Within European Union Enlargement to Central and Eastern European Countries", The Swiss Review of International Economic Relations, 63 (3), 309-328

[35] Robinson, J. (1947), Essays in the Theory of Employment, Oxford: Basil Blackwell.

[36] Roodman D. (2009a), "How to do xtabond2: An introduction to difference and system GMM in Stata", Stata Journal, 9(1), 86-136.

[37] Roodman D. (2009b), "A Note on the Theme of Too Many Instruments", Oxford Bulletin of Economics and Statistics, 71(1), 135-158.

[38] Santos-Paulino A.U. (2002), "The Effects of Trade Liberalization on Imports in Selected Developing Countries", World Development, 30,959-974

[39] Santos-Paulino A.U., Thirlwall A. P. (2004), “The Impact of Trade Liberalisation on Exports, Imports, and the Balance of Payments of Developing Countries", Economic Journal, 114,50-72.

[40] Serlenga L., Shin Y. (2007), "Gravity models of intra-EU trade : Application of the CCEP-HT estimation in heterogenous panels with unobserved common time-specific factors", Journal of applied econometrics, 22,361-381 
[41] Soloaga I., Winters A.L., (2001), "Regionalism in the nineties: what effect on trade?", The North American Journal of Economics and Finance, Elsevier, 12(1),1-29. [42] Tang C.T., (2008), "Determinants of Malaysian Trade Balance: An ARDL Bound Testing Approach -A Commentary”, Global Economic Review, 37 (1),125-133

[43] Thomas V., Nash J., Edwards S. (1991), "Best Practices in Trade Policy Reform”, Oxford University Press for the World Bank.

[44] Tinbergen J. (1962), "Shaping the World Economy: Suggestions for an International Economic Policy", Twentieth Century Fund, New York.

[45] UNCTAD (1999), "Trade and Development Report", Geneva

[46] Wu Y., Zeng L. (2008), "The Impact of Trade Liberalization on the Trade Balance in Developing Countries", IMF Working Paper 


\section{APPENDIX}

\section{The correlated common estimation pooled - Hausman-Taylor (CCEP-HT)}

Here, we present briefly the CCEP-HT method developed by Serlenga and Shin (2007). The variables used in the estimated models are listed in Table 2 in the paper. The panel data model can be written as:

$$
y_{i t}=\beta^{\prime} x_{i t}+\gamma^{\prime} z_{i}+\varepsilon_{i t} \mathrm{i}=1, \ldots \ldots \mathrm{N}, \mathrm{t}=1, \ldots \ldots \mathrm{T}
$$

with

$$
\varepsilon_{i t}=\alpha_{i}+\theta_{t}+u_{i t}
$$

where: $x_{i t}$ is a $\mathrm{k} \mathrm{x} 1$ vector of time-varying variables;

$\mathrm{z}_{\mathrm{i}}$ is a $\mathrm{g} \mathrm{x} 1$ vector of variables fixed over time;

$\alpha_{i}$ are individuals specific effects that might be correlated with $x_{i t}$ and $z_{i}$;

$\theta_{\mathrm{t}}$ are time-specific effects common to all cross-section units;

$\mathrm{u}_{\mathrm{it}}$ are mean idiosyncratic random disturbances uncorrelated across cross-section units and over time periods.

Usually $\theta_{\mathrm{t}}$ is used to measure common policies or macroeconomic shocks, and this imposes homogeneity of individual response with respect to time specific-effect. The homogeneous structure of (A7) can be generalised by writing it as:

$$
y_{i t}=\beta^{\prime} x_{i t}+\gamma^{\prime} z_{i}+\pi_{i}^{\prime} s_{t}+\varepsilon_{i t}, \mathrm{i}=1, \ldots \ldots \mathrm{N}, \mathrm{t}=1, \ldots \ldots \mathrm{T}
$$

with

$$
\varepsilon_{i t}=\alpha_{i}+\varphi_{i} \theta_{t}+u_{i t}
$$

where: $s_{t}=\left(s_{1 t}, \ldots . s_{s t}\right)^{\prime}$ is a s x 1 vector with a parameter vector, $\pi_{i}=\left(\pi_{1 i} \ldots \pi_{\mathrm{si}}\right)^{\prime}$, of observed time-specific factors ; and $\varphi_{\mathrm{i}}$ capture heterogeneous individual responses with respect to the unobserved common time-specific effects, $\theta_{\mathrm{t}}$.

Following Hausman and Taylor (1981) equation (A9) can be written as: 


$$
y_{i t}=\beta_{1}^{\prime} x_{i t}^{1}+\beta_{2}^{\prime} x_{i t}^{2}+\gamma_{1}^{\prime} z_{i}^{1}+\gamma_{2}^{\prime} z_{i}^{2}+\pi_{i}^{\prime} s_{t}+\varepsilon_{i t}
$$

where:

$\mathrm{x}^{1}{ }_{\mathrm{it}}, \mathrm{x}^{2}{ }_{\text {it }}$ are $\mathrm{k}_{1} \mathrm{x} 1$ and $\mathrm{k}_{2} \mathrm{x} 1$ vectors, $\mathrm{z}_{\mathrm{i}}^{1}, \mathrm{z}^{2}{ }_{\mathrm{i}}$ are $\mathrm{g}_{1} \mathrm{x} 1$ and $\mathrm{g}_{2} \mathrm{x} 1$ vectors, and $\beta_{1}, \beta_{2}, \gamma_{1}$, $\gamma_{2}$ are conformably vectors of parameters, under the following assumptions:

(i) $\mathrm{u}_{\mathrm{it}} \sim$ i.i.d. $\left(0, \sigma^{2}{ }_{\mathrm{it}}\right)$;

(ii) $\alpha_{\mathrm{I}} \sim$ i.i.d. $\left(\alpha, \alpha_{\alpha}^{2}\right)$;

(iii) $\mathrm{E}\left(\alpha_{\mathrm{i}}, \mathrm{u}_{\mathrm{it}}\right)=0, \mathrm{E}\left(\theta_{\mathrm{t}}, \mathrm{u}_{\mathrm{jt}}\right)=0$ for all $\mathrm{i}, \mathrm{j}, \mathrm{t}$;

(iv) $\mathrm{E}\left(\mathrm{x}_{\mathrm{i}}, \mathrm{u}_{\mathrm{js}}\right)=0$ and $\mathrm{E}\left(\mathrm{z}_{\mathrm{i}}, \mathrm{u}_{\mathrm{jt}}\right)=0$ for all $\mathrm{i}, \mathrm{j}, \mathrm{s}, \mathrm{t}$, so all regressors are exogenous with respect to the idiosyncratic errors, $\mathrm{u}_{\mathrm{it}}$;

(v) $\mathrm{x}^{1}{ }_{\text {it }}$ and $\mathrm{z}^{1}{ }_{\mathrm{i}}$ are uncorrelated with $\alpha_{\mathrm{I}}$ for all $\mathrm{i}, \mathrm{t}$, whereas $\mathrm{x}^{2}{ }_{\text {it }}$ and $\mathrm{z}_{\mathrm{i}}^{1}$ are uncorrelated with $\alpha_{\mathrm{I}}$;

(vi) both $\mathrm{N}$ and $\mathrm{T}$ are sufficiently large.

Assumptions $\mathbf{i} \rightarrow \mathbf{v}$ are standard in the panel data literature ${ }^{10}$. Assumption (vi) is necessary for consistent estimation of heterogeneous parameters. If cross-section dependence of the errors in (10) is ignored, there is substantial estimation bias for $\beta$ (Pesaran, 2006). Following the Correlated Common Effect Pooled (CCEP) ${ }^{11}$ estimation approach advanced by Pesaran (2006), equation (A9) can be written as:

$$
y_{i t}=\beta^{\prime} x_{i t}+\gamma^{\prime} z_{i}+\lambda_{i}^{\prime} f_{t}+\alpha_{i}^{*}+u_{i t}^{*}, \mathrm{I}=1, \ldots, \mathrm{N}, \mathrm{t}=1, \ldots, \mathrm{T}
$$

where :

$f_{t}=\left(s_{t}^{i}, \bar{y}_{t}, \bar{x}_{t}^{\prime}\right)^{\prime}$ is a $\mathrm{m} \times 1$ vector of augmented time-specific factors with $\mathrm{m}=\mathrm{s}+1+\mathrm{k}$;

$\bar{y}_{t}=\sum_{i=1}^{N} y_{i t} / N ; \bar{x}_{t}=\sum_{i=1}^{N} x_{i t} / N$

$\lambda_{i}^{\prime}=\left(\pi_{i}^{\prime}-\left(\varphi_{i} / \bar{\varphi}_{i}\right) \bar{\pi}^{\prime},\left(\varphi_{i} / \bar{\varphi}_{i}\right),-\left(\varphi_{i} / \bar{\varphi}_{i}\right) \beta^{\prime}\right)^{\prime}$ with $\bar{\varphi}=\sum_{i=1}^{N} \varphi_{i} / N$ and $\bar{\pi}=\sum_{i=1}^{N} \pi_{i} / N$

$\alpha_{i}^{*}=\alpha_{i}-\left(\varphi_{i} / \bar{\varphi}_{i}\right) \bar{\alpha}-\left(\varphi_{i} / \bar{\varphi}_{i}\right) \gamma^{\prime} \bar{z} \quad$ with $\bar{\alpha}=\sum_{i=1}^{N} \alpha_{i} / N \quad$ and $\bar{z}=\sum_{i=1}^{N} z_{i} / N$

\footnotetext{
${ }^{10}$ See Hausman and Taylor (1981)

${ }^{11}$ The CCEP estimator is obtained as the generalized within estimator applied to the panel data regression augmented with cross-sectional averages of $\mathrm{y}_{\mathrm{it}}$ and $\mathrm{x}_{\mathrm{it}}$ that consistently replace unobserved common timespecific effects.
} 
and $u_{i t}^{*}=u_{i t}-\left(\varphi_{i} / \bar{\varphi}_{i}\right) \bar{u}_{t}$ with $\bar{u}_{t}=\sum_{i=1}^{N} u_{i t} / N$

If the pooling weight equal to $\mathrm{N}^{-1}$, the CCEP estimator of $\beta$ is given by :

$$
\hat{\beta}_{C C E P}=\frac{\sum_{i=1}^{N} x_{i}^{\prime} M_{T} y_{i}}{\sum_{i=1}^{N} x_{i}^{\prime} M_{T} x_{i}}
$$

where:

$$
\underset{(T x 1)}{y_{i}}=\left(\begin{array}{l}
y_{i 1} \\
y_{i 2} \\
. . \\
y_{i T}
\end{array}\right) \quad \underset{(T x 1)}{x_{i}}=\left(\begin{array}{l}
x_{i 1} \\
x_{i 2} \\
. . \\
x_{i T}
\end{array}\right) \quad \underset{(T x 1)}{f}=\left(\begin{array}{l}
f_{1} \\
f_{2} \\
. . \\
f_{T}
\end{array}\right) \underset{(T x 1)}{1_{T}}=\left(\begin{array}{l}
1 \\
1 \\
. . \\
1
\end{array}\right) \quad \mathrm{H}_{\mathrm{T}}=\left(1_{\mathrm{T}}, \mathrm{f}\right)
$$

and $M_{T}=I_{T}-H_{T}\left(H_{T}^{\prime} H_{T}\right)^{-1} H_{T}^{\prime}$

Pesaran (2006) shows that the CCEP estimator $\hat{\beta}_{\text {CCEP }}$ is consistent under fairly standard regularity conditions and under the assumption that all the variables are stationary, and that it wipes out any individual specific variables in $z_{i}$ from (A11).

Equation (A12) can be written as:

$$
d_{i t}=\gamma_{1}^{\prime} z_{i}^{1}+\gamma_{2}^{\prime} z_{i}^{2}+\alpha_{i}^{*}+u_{i t}^{*}=\mu+\gamma^{\prime} z_{i}+\varepsilon_{i t}^{*} \quad \mathrm{i}=1, \ldots, \mathrm{N}, \mathrm{t}=1, \ldots, \mathrm{T}
$$

where: $\quad d_{i t}=y_{i t}-\beta^{\prime} x_{i t}-\lambda_{i}^{\prime} f_{t} ; \mu=E\left(\alpha_{i}^{*}\right)$ and $\varepsilon_{i t}^{*}=\left(\alpha_{i}^{*}-\mu\right)+u_{i j}^{*}$ is by construction a zero mean process.

Equation (A14) can be written in matrix notation as:

$$
d=\mu 1_{N T}+Z^{1} \gamma_{1}+Z^{2} \gamma_{2}+\varepsilon^{*}
$$

Replacing d by its consistent estimate, (A15) can be written as:

$$
\hat{d}=\mu 1_{N T}+Z^{1} \gamma_{1}+Z^{2} \gamma_{2}+\bar{\varepsilon}=C \delta+\varepsilon^{+}
$$

where: $\hat{d}=\left(\hat{d}_{i t}, i=1, \ldots N ; t=1, \ldots . T\right) ; \quad \hat{d}_{i t}=y_{i t}-\hat{\beta}_{C C E P}^{\prime} x_{i t}-\hat{\lambda}_{i}^{\prime} f_{t}$ and $\hat{\lambda}_{i}$ are the OLS consistent estimators of $\lambda_{\mathrm{i}}$ from the regression of $\left(y_{i t}-\hat{\beta}_{C}^{\prime} x_{i t}\right)$ on $\left(1, \mathrm{f}_{\mathrm{t}}\right)$

$$
\varepsilon^{+}=\varepsilon^{*}+(\hat{d}-d) ; C=\left(1_{N T}, Z^{1}, Z^{2}\right) ; \delta=\left(\mu, \gamma_{1}^{\prime}, \gamma_{2}^{\prime}\right)
$$


The following NT $x\left(1+g_{1}+h\right)$ matrix of instrument variables

$$
\mathrm{W}=\left(\mathrm{l}_{\mathrm{NT}}, \mathrm{Z}^{1}, \mathrm{~W}_{2}\right)
$$

is required to deal with non-zero correlation between $Z^{2}$ and $\alpha$.

where: $\mathrm{W}_{2}$ is an NT $\mathrm{x} \mathrm{h}$ matrix of instrumental variables for $\mathrm{Z}^{2}$ (for identification it is necessary that $\mathrm{h} \geq \mathrm{g}_{2}$ ). The advantage of the Hausman-Taylor estimation method is that the instrumental variables for $\mathrm{Z}^{2}$ can be obtained internally, using $\Phi \mathrm{X}_{1}$ as instruments for $\mathrm{Z}^{2}$, where $\Phi=\Omega\left(\Omega \Omega^{-1} \Omega^{\prime}\right.$ is an idempotent matrix NT x NT, $\Omega=\mathrm{I}_{\mathrm{N}} \otimes \mathrm{I}_{\mathrm{T}}$ and $\mathrm{I}_{\mathrm{N}}$ is a N x $\mathrm{N}$ identity matrix.

Serlenga and Shin (2007) proposed an alternative instrument matrix for $\mathrm{Z}^{2}$

$$
W_{2}=\left(\Phi X_{1}, \Phi \hat{\eta}_{1}, \Phi \hat{\eta}_{2}, \ldots \ldots . . \Phi \hat{\eta}_{m}\right)
$$

where $: \bar{\eta}_{j}=\left(\hat{\lambda}_{j 1}, f_{j}^{\prime}, \hat{\lambda}_{j 2}, f_{j}^{\prime} \ldots \ldots \ldots \hat{\lambda}_{j N}, f_{j}^{\prime}\right)^{\prime} \mathrm{j}=1, \ldots .1, \mathrm{f}_{\mathrm{j}}=\left(\mathrm{f}_{\mathrm{j} 1}, \ldots . \mathrm{f}_{\mathrm{jT}}\right)^{\prime}$ and $\hat{\eta}_{j}$ is assumed to be correlated with $\mathrm{z}_{\mathrm{i}}^{2}$ but not correlated with $\alpha_{\mathrm{I}}$ for $\mathrm{j}=\left(1, \ldots \mathrm{m}_{1}\right)$, while $\hat{\eta}_{j}$ are correlated with both $\mathrm{z}_{\mathrm{i}}^{2}$ and $\alpha_{\mathrm{I}}$ for $\mathrm{j}=\left(\mathrm{m}_{1}+1, \ldots \mathrm{m}\right)$.

Using Monte Carlo methods, Serlenga and Shin (2007) showed that the small sample performance of the CCEP-HT estimator is indeed much superior to that of the two-way FE-HT estimator in the presence of unobserved heterogeneous common factor in panels. Their study confirms that an inappropriate treatment of heterogeneous common unobserved factors implies severely biased estimates. For a more detailed presentation of CCEP-HT method see Serlenga and Shin (2007). 
Table 3 - The impact of the association agreements on exports

\begin{tabular}{|c|c|c|}
\hline Method & CCEP-HT & GMM \\
\hline Equation & (11) & (13) \\
\hline VARIABLES & $\mathbf{X}_{\mathrm{ijt}}$ & $\mathbf{X}_{\mathrm{ijt}}$ \\
\hline \multirow{2}{*}{$\mathbf{X}_{\mathrm{ijt}-1}$} & - & 0.695 \\
\hline & - & $(16.15) * * *$ \\
\hline \multirow[t]{2}{*}{$\mathbf{G D P}_{\text {it }}$} & 1.227 & 1.015 \\
\hline & $(4.89)^{* * *}$ & $(27.21)^{* * *}$ \\
\hline \multirow{2}{*}{$\mathbf{G D P}_{\mathbf{j t}}$} & 1.462 & 1.037 \\
\hline & $(4.76) * * *$ & $(18.17) * * *$ \\
\hline \multirow[t]{2}{*}{ Dist $_{\mathrm{ij}}$} & -0.918 & -1.062 \\
\hline & $(4.16)^{* * *}$ & $(8.49) * * *$ \\
\hline \multirow{2}{*}{ DGDPT $_{\mathrm{ijt}}$} & 0.187 & 0.152 \\
\hline & $(1.77)^{*}$ & $(6.67)^{* * *}$ \\
\hline \multirow[t]{2}{*}{$\mathbf{R E R}_{\mathrm{ijt}}$} & -0.026 & -0.017 \\
\hline & $(1.85)^{*}$ & $(12.37) * * *$ \\
\hline \multirow{2}{*}{$\mathbf{E A}_{\mathrm{ijt}}$} & 0.311 & 0.235 \\
\hline & $(9.39) * * *$ & $(10.20) * * *$ \\
\hline \multirow[t]{2}{*}{$\mathbf{P S}_{\text {it }}$} & 0.167 & 0.079 \\
\hline & $(6.22) * * *$ & $(2.97) * * *$ \\
\hline \multirow[t]{2}{*}{$\mathbf{C B}_{\mathrm{ij}}$} & 0.417 & 0.256 \\
\hline & $(1.86)^{*}$ & $(5.87) * * *$ \\
\hline \multirow[t]{2}{*}{$\mathbf{L}_{\mathbf{i j}}$} & 0.287 & 0.196 \\
\hline & $(2.93) * * *$ & $(3.19) * * *$ \\
\hline \multirow[t]{2}{*}{ Constant } & 7.612 & 6.322 \\
\hline & $(5.87)^{* * *}$ & $(21.57) * * *$ \\
\hline Observations & 1200 & 1064 \\
\hline Number of groups & 56 & 56 \\
\hline \multirow{2}{*}{$\begin{array}{l}\text { Sargan test of overid. restrictions: chi2 } \\
\text { Prob > chi2 }\end{array}$} & 0.952 & 3.28 \\
\hline & $(0.329)$ & $(0.916)$ \\
\hline \multirow{2}{*}{$\begin{array}{l}\text { Arellano-Bond test for AR(1) in first } \\
\text { differences: } \mathrm{z} \\
\text { Prob>z }\end{array}$} & - & -0.85 \\
\hline & - & $(0.396)$ \\
\hline \multirow{2}{*}{$\begin{array}{l}\text { Arellano-Bond test for AR(2) in first } \\
\text { differences: } \mathrm{z} \\
\text { Prob>z }\end{array}$} & - & -0.23 \\
\hline & - & $(0.821)$ \\
\hline \multicolumn{3}{|l|}{ Robust t statistics in parentheses } \\
\hline \multicolumn{3}{|c|}{$*$ significant at $10 \% ; * *$ significant at $5 \% ; * * *$ significant at $1 \%$} \\
\hline \multicolumn{3}{|c|}{ 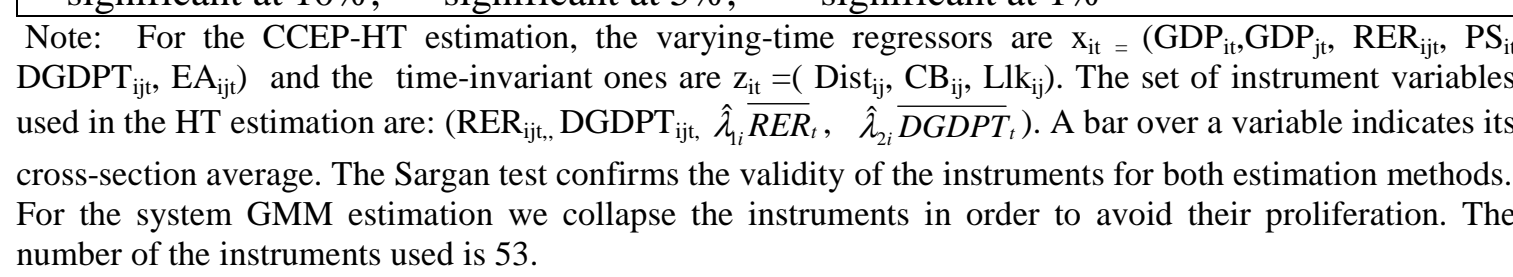 } \\
\hline
\end{tabular}


Table 4 - The impact of the association agreements on imports

\begin{tabular}{|c|c|c|}
\hline Method & CCEP-HT & GMM \\
\hline Equation & (12) & (14) \\
\hline VARIABLES & $\mathbf{M}_{\mathrm{ijt}}$ & $\mathbf{M}_{\mathrm{ijt}}$ \\
\hline \multirow{2}{*}{$\mathbf{M}_{\mathrm{ijt}-1}$} & - & 0.735 \\
\hline & - & $(22.34) * * *$ \\
\hline \multirow[t]{2}{*}{ GDP $_{\text {it }}$} & 1.047 & 0.963 \\
\hline & $(8.38)^{* * *}$ & $(28.71)^{* * * *}$ \\
\hline \multirow[t]{2}{*}{$\mathbf{G D P}_{\mathbf{j t}}$} & 0.975 & 0.892 \\
\hline & $(7.96) * * *$ & $(17.21)^{* * *}$ \\
\hline \multirow[t]{2}{*}{ Dist $_{i j}$} & -0.832 & -1.121 \\
\hline & $(3.31)^{* * * *}$ & $(7.38) * * *$ \\
\hline \multirow[t]{2}{*}{ DGDPT $_{i j t}$} & 0.351 & 0.215 \\
\hline & $(4.87) * * *$ & $(2.39)^{* *}$ \\
\hline \multirow[t]{2}{*}{$\mathbf{R E R}_{\mathrm{ijt}}$} & 0.069 & 0.011 \\
\hline & $(1.86)^{*}$ & $(2.29)^{* *}$ \\
\hline \multirow[t]{2}{*}{$\mathbf{E A}_{\mathrm{ijt}}$} & 0.425 & 0.357 \\
\hline & $(9.51)^{* * *}$ & $(10.32)^{* * *}$ \\
\hline \multirow[t]{2}{*}{$\mathbf{P S}_{\text {it }}$} & 0.117 & 0.065 \\
\hline & $(4.33) * * *$ & $(9.57) * * *$ \\
\hline \multirow{2}{*}{$\mathrm{CB}_{\mathrm{ij}}$} & 0.427 & 0.261 \\
\hline & $(1.79)^{*}$ & $(4.97) * * *$ \\
\hline \multirow[t]{2}{*}{$\mathbf{L l k}_{\mathrm{ij}}$} & 0.511 & 0.215 \\
\hline & $(4.04)^{* * *}$ & $(5.63) * * *$ \\
\hline \multirow[t]{2}{*}{ Constant } & -7.943 & -6.536 \\
\hline & $7.40 * * *$ & $(12.33)^{* * *}$ \\
\hline Observations & 1200 & 1064 \\
\hline Number of groups & 56 & 56 \\
\hline \multirow{2}{*}{$\begin{array}{l}\text { Sargan test of overid. restrictions: chi2 } \\
\text { Prob > chi2 }\end{array}$} & 1.200 & 1.94 \\
\hline & $(0.316)$ & $(0.963)$ \\
\hline \multirow{2}{*}{$\begin{array}{l}\text { Arellano-Bond test for AR(1) in first } \\
\text { differences: } z \\
\text { Prob>z }\end{array}$} & - & -0.60 \\
\hline & - & $(0.550)$ \\
\hline \multirow{2}{*}{$\begin{array}{l}\text { Arellano-Bond test for AR(2) in first } \\
\text { differences: } z \\
\text { Prob>z }\end{array}$} & - & 0.10 \\
\hline & - & $(0.922)$ \\
\hline
\end{tabular}

Note: For the CCEP-HT estimation, the varying-time regressors are $x_{i t}=\left(\mathrm{GDP}_{\mathrm{it}}, \mathrm{GDP}_{\mathrm{it}}, \mathrm{RER}_{\mathrm{it}}, \mathrm{PS}_{\mathrm{it}}\right.$ $\left.\operatorname{DGDPT}_{\mathrm{ij}}, \mathrm{EA}_{\mathrm{ij}}\right)$ and the time-invariant ones are $\mathrm{z}_{\mathrm{it}}=\left(\mathrm{Dist}_{\mathrm{ij}}, \mathrm{CB}_{\mathrm{ij}}, \mathrm{Ll}_{\mathrm{ij}}\right)$. The set of instrument variables used in the $\mathrm{HT}$ estimation are: $\left(\mathrm{RER}_{\mathrm{ijt}, \text {, }}, \mathrm{DGPT}_{\mathrm{ij},}, \hat{\lambda}_{i i} \overline{R E R_{t}}, \hat{\lambda}_{2 i} \overline{D G D P T_{t}}\right)$. A bar over a variable indicates its cross-section average. The Sargan test confirms the validity of the instruments for both estimation methods. For the system GMM estimation we collapse the instruments in order to avoid their proliferation. The number of the instruments used is 53 . 
Table 5 - The impact of the association agreements on the trade balance

\begin{tabular}{|c|c|c|}
\hline Method & GMM & GMM \\
\hline Equation & (15) & $(16)$ \\
\hline VARIABLES & $\mathbf{T B}_{\mathrm{ijt}}$ & $\mathbf{T B}_{\mathrm{ijt}} / \mathrm{GDP}$ \\
\hline \multirow[t]{2}{*}{$\mathbf{T B}_{\mathrm{ijt}-1}$} & 0.617 & 0.584 \\
\hline & $(8.13) * * *$ & $(52.88) * * *$ \\
\hline \multirow[t]{2}{*}{ GDPR $_{\text {it }}$} & -0.042 & -0.015 \\
\hline & $(1.87)^{*}$ & $(8.07)^{* * *}$ \\
\hline \multirow[t]{2}{*}{$\mathbf{G D P R}_{\mathbf{j t}}$} & 0.114 & 0.056 \\
\hline & $(7.31) * * *$ & $(8.70) * * *$ \\
\hline \multirow[t]{2}{*}{ DGDPTR $_{\mathrm{ijt}}$} & -0.089 & -0.025 \\
\hline & $(2.53)^{* *}$ & $(6.35)^{* * *}$ \\
\hline \multirow[t]{2}{*}{$\mathbf{R E R}_{\mathrm{ijt}}$} & -0.018 & -0.011 \\
\hline & $(2.83)^{* *}$ & $(1.63)^{* *}$ \\
\hline \multirow[t]{2}{*}{$\mathbf{E A}_{\mathrm{ijt}}$} & -0.172 & -0.119 \\
\hline & $(6.31)^{* * * *}$ & $(6.89)^{* * *}$ \\
\hline \multirow[t]{2}{*}{$\mathbf{P S}_{\text {it }}$} & 0.007 & 0.004 \\
\hline & $(1.83)^{*}$ & $(1.95)^{*}$ \\
\hline \multirow[t]{2}{*}{$\mathrm{CB}_{\mathrm{ij}}$} & 0.019 & 0.009 \\
\hline & $(1.68)^{*}$ & $(0.92)$ \\
\hline \multirow[t]{2}{*}{$\mathbf{L}_{\mathbf{i j}}$} & 0.062 & 0.051 \\
\hline & $(1.73)^{*}$ & $(2.35)^{* *}$ \\
\hline \multirow[t]{2}{*}{ Constant } & -0.334 & -0.191 \\
\hline & $(5.12) * * *$ & $(7.01)^{* * * *}$ \\
\hline Observations & 1064 & 1064 \\
\hline Number of groups & 56 & 56 \\
\hline \multirow{2}{*}{$\begin{array}{l}\text { Sargan test of overid. restrictions: chi2 } \\
\text { Prob > chi2 }\end{array}$} & 7.81 & 4.89 \\
\hline & $(0.648)$ & $(0.558)$ \\
\hline \multirow{2}{*}{$\begin{array}{l}\text { Arellano-Bond test for AR(1) in first differences: } \mathrm{z} \\
\text { Prob }>\mathrm{z}\end{array}$} & -1.38 & -0.61 \\
\hline & $(0.168)$ & $(0.541)$ \\
\hline \multirow{2}{*}{$\begin{array}{l}\text { Arellano-Bond test for AR(2) in first differences: } \mathrm{z} \\
\text { Prob>z}\end{array}$} & 0.24 & -1.49 \\
\hline & $(0.813)$ & $(0.136)$ \\
\hline
\end{tabular}

Note: For the system GMM estimation we collapse the instruments in order to avoid their proliferation.

The number of the instruments used is 53. The Sargan test confirms the validity of the instruments for both estimation methods. 
Chart 1a - Evolution of the trade balance of the CEEC-4 with the EU -15

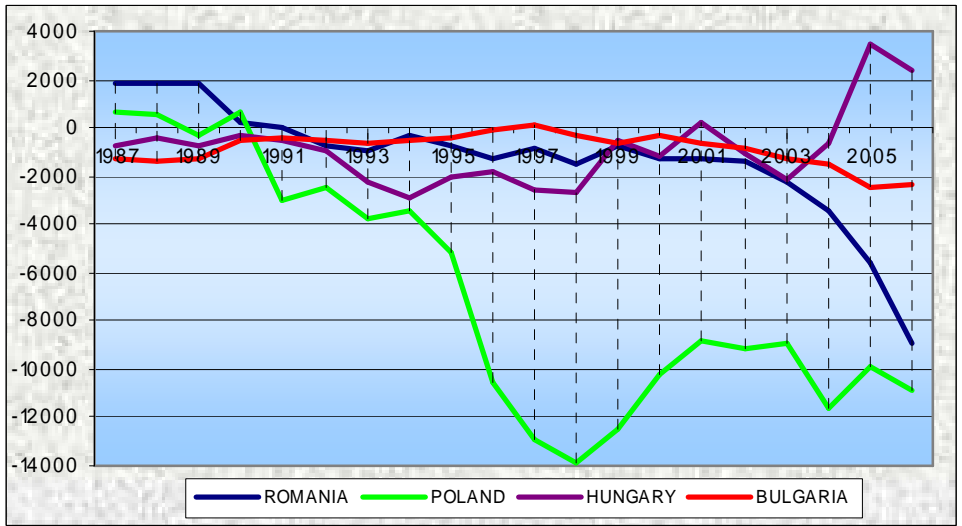

Data source: Chelem data base. Calculations by the authors

Chart 1b - Evolution of the trade balance ratio to GDP of the CEEC-4 with the EU -15

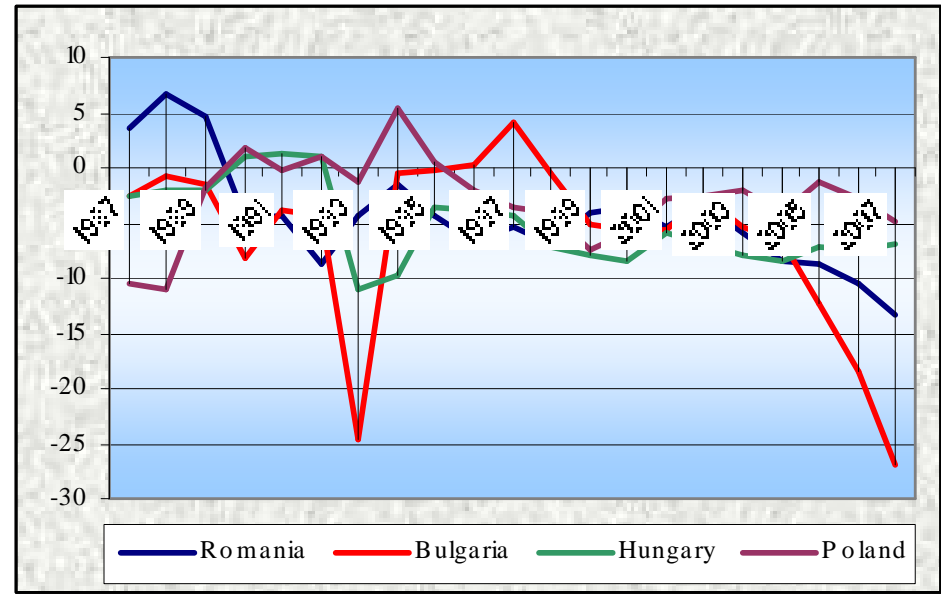

Data source: IMF data base

Chart 2.a - Evolution of exports, imports and trade balance of Romania with EU-15

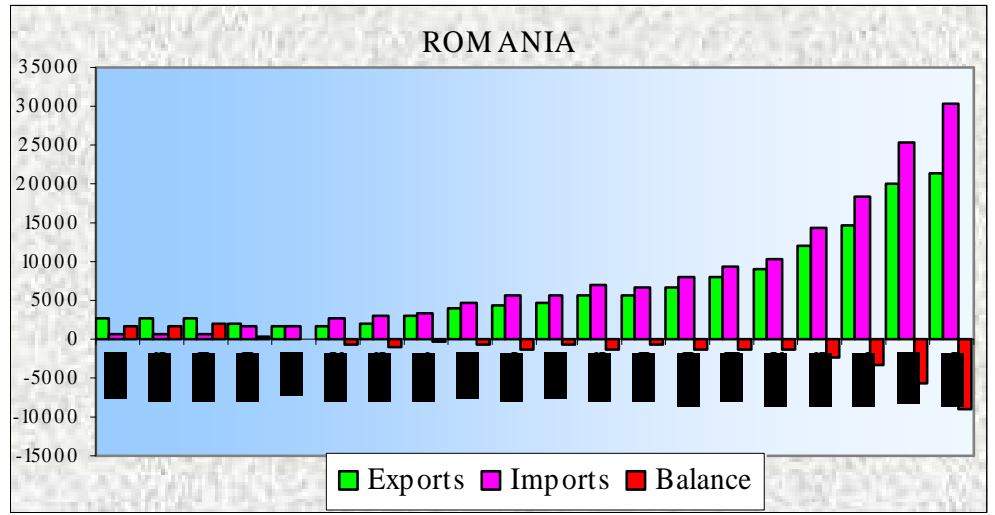

Data source: Chelem data base. Calculations by the authors 
Chart 2.b - Evolution of exports, imports and trade balance of Poland with EU-15

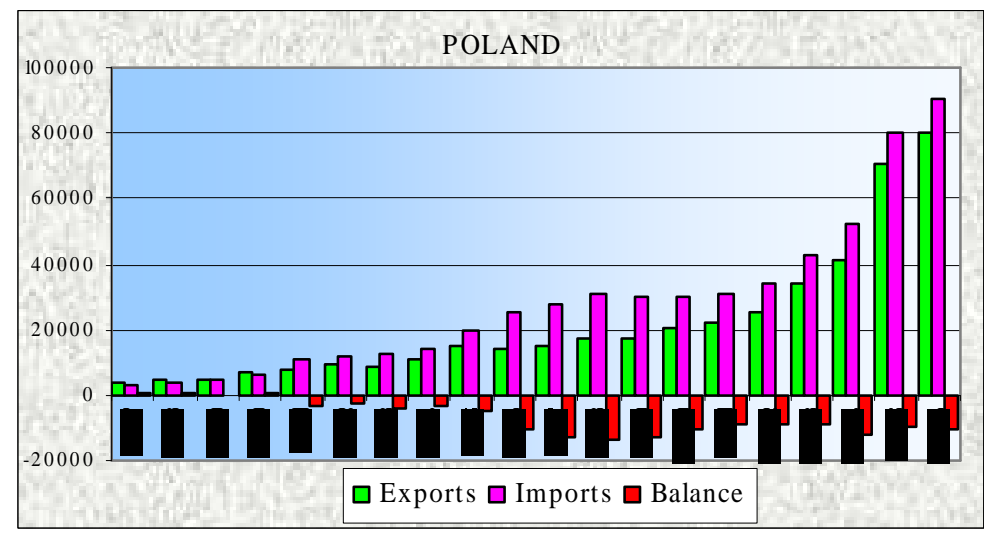

Data source: Chelem data base. Calculations by the authors

Chart 2.c - Evolution of exports, imports and trade balance of Hungary with EU-15

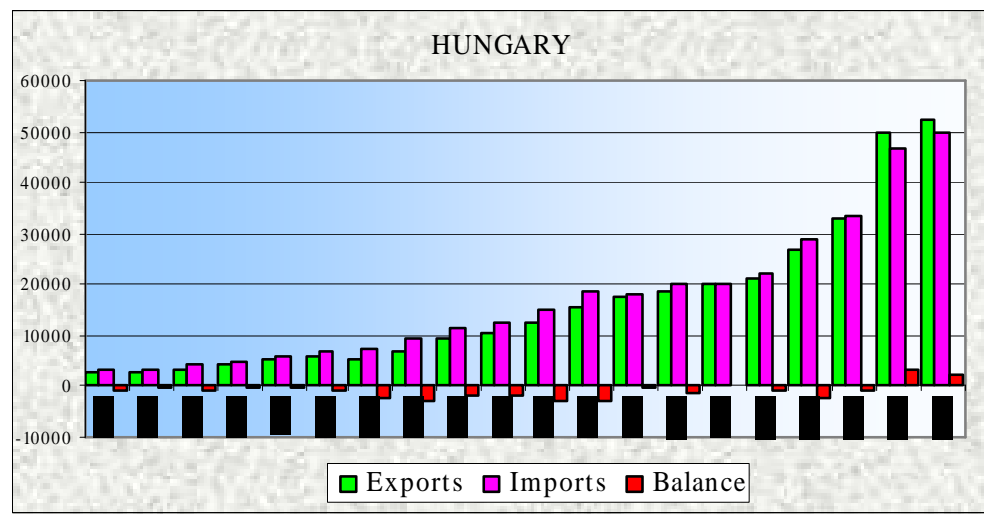

Data source: Chelem data base. Calculations by the authors

Chart 2.d - Evolution of exports, imports and trade balance of Bulgaria with EU-15

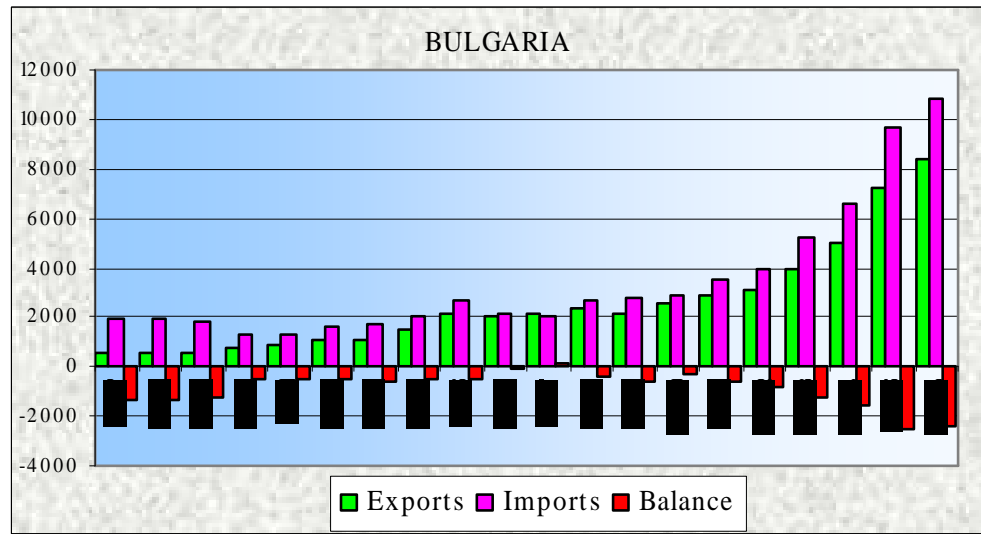

Data source: Chelem data base. Calculations by the authors 
Chart 3 - Imports of intermediate goods and equipment as a \% of total imports, 2004

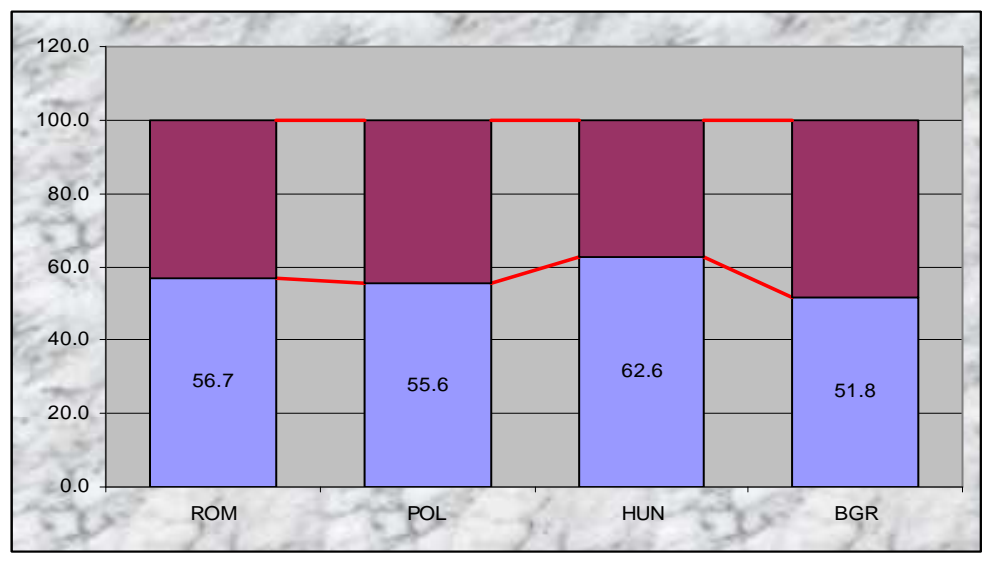

Data source: Chelem data base. Calculations by the authors 